Trinity University

Digital Commons @ Trinity

Modern Languages and Literatures Faculty

Research

Modern Languages and Literatures Department

Spring 2004

\title{
The Director's Cut: Baroque Aesthetics and Modern Stagings of the Comedia
}

Matthew D. Stroud

Trinity University, mstroud@trinity.edu

Follow this and additional works at: https://digitalcommons.trinity.edu/mll_faculty

Part of the Modern Languages Commons

\section{Repository Citation}

Stroud, M.D. (2004). The director's cut: Baroque aesthetics and modern stagings of the Comedia. Comedia Performance, 1(1), 77-94.

This Article is brought to you for free and open access by the Modern Languages and Literatures Department at Digital Commons @ Trinity. It has been accepted for inclusion in Modern Languages and Literatures Faculty Research by an authorized administrator of Digital Commons @ Trinity. For more information, please contact jcostanz@trinity.edu. 


\title{
The Director's CuT: Baroque Aes- THETICS AND MODERN STAGINGS OF THE COMEDIA
}

\author{
MATTHEW D. STROUD \\ Trinity University
}

The last twenty-five years have witnessed a relative explosion in the number of staged productions of Spanish comedias. Whether the performances take place in Madrid, Almagro, New York, or El Paso, the experience has changed forever the way those who have attended performances view plays previously known only by reaing the text. One cannot fail to have been affected by the interaction between literature and theater, between professors and directors, between text and performance. A debate that has arisen as a result of this spectator's experience, especially after the production of a particularly well-known comedia, is that between authorial intention and directorial vision. The differences between the two perspectives on any given play have led to a great deal of polemical criticism, usually focusing on the authority of the text versus the rights of the director, or the relative meaning of a 
text for audiences in different cultures and eras. Unfortunately, advocates of neither side seem capable to win over converts, at least not quickly or easily, but the ongoing process of engaging this question year after year has definitely altered the way comediantes speak of both the text and the performance. Perhaps two notions put forth by Jonathan Miller in The Afterlife of Plays might be of use. First, works of art always change, whether by intentional reworking or the incidental wear and tear that inevitably occurs over time. For Miller, "the history of art is partly, not altogether, but quite significantly, the history of damage and injury and plagiarism and theft and robbery and violence of one sort or another" (41). Second, theatrical works of art are allographic rather than autographic in nature. Unlike the singular work that has a physical existence, such as a painting or a work of sculpture, theatrical art is always a representation subject to change even from one performance to the next. Miller is unconcerned by radical changes introduced by a director's vision; after all, "the text continues to live to be performed another day" (41).

The purpose of the present study is not to reopen the larger debate that has been known to degenerate into a kind of professional name-calling in which professors of literature and directors accuse each other of high crimes and misdemeanors. (As an indication of the level of invective, consider the comment of John Igo, a famous local director and professor in San Antonio, who said during a meeting about the 1981 staging of Calderón's Celos aun 
del aire matan at Trinity University, "I came for the smell of grease paint, and all I got was embalming fluid.") Instead, the focus here will be on a rather limited area, specifically how comedias are cut when they are staged for modern audiences and the effects of those cuts on our aesthetic appreciation of the genre. While it is tempting to use the most exceptional stagings, updated versions, and mélanges as examples, in order for these remarks to have the widest currency, the attention will be on those productions that actually strive to present the plays as works of a certain place and time.

At the same time, a discussion regarding authenticity in general would be wide-ranging indeed, and many of the factors of original staging are either poorly known or completely beyond our knowledge and are probably lost forever. Among the myriad questions regarding comedia performance are a few that we are simply not prepared to answer at this time: How was a particular play acted? How did diction vary from performance to performance and over time? What did the costumes look like? How did the distractions of the audience affect performance? What text was actually used for any particular performance? This last factor is an exceptionally thorny issue given the generally suspect provenance of many of the most famous comedias and the role of the intervening autor de comedias. The text we read was almost assuredly not presented exactly as it was later printed; cuts and revisions are an inevitable part of the performance process. Modern productions also cut text, but I suspect that the cuts are 
made for different reasons and have different results.

Conversations at Chamizal and other venues reveal that no matter how many comedias one has seen performed (and there are doubtless those who have seen 100 or more), it is safe to say that not one has presented all the text that traditionally read in the study of the plays as literature, and rarely is the text organized as it is in the original; at the very least, the plays are almost universally presented in two acts rather than in three. There are, of course, compelling reasons for textual cuts, and any director of older literature, in any language, will gladly recite a long list of exigencies: the competencies of the actors, the accessibility of the syntax and vocabulary, or the length of the audience's attention span (or, in the words of Gilbert Denman, another important figure in San Antonio theater put it, the mind's attention lasts only as long as the derrière holds out). Lee Mitchell, in Staging Premodern Drama, seems to agree: "Cutting of lines becomes necessary when the text is too long to be performed within comfortable limits" (13). As Sidney Berger of the University of Houston states it regarding his stagings of Shakespeare, "I do cut because sixteenthcentury audiences were different from those in our time" (46). In a concrete sense, there can be simply no doubt that most modern audiences may not be accustomed to foreign theatrical experiences, whether from other cultures or other periods, especially in light of the increasing narrative expectations created by the more readily available and dis- 
cursive cinematic media. A common belief is that modern audiences will not accept certain established conventions of baroque theater, with "baroque" used imprecisely as a cover term for the various artistic ideals of the late sixteenth and early seventeenth century, including characteristics of both the baroque and mannerism, and not in the more limited definition proposed by Hatzfeld (22433). The comedia performance was intentionally much more than just characters acting out a set plot. It was an event: a full afternoon of entertainment, made extremely long by the inclusion of short pieces performed during intermissions, and the occasional cessation of plot to showcase flights of poetry marked by culteranismo, conceptismo, anaphora, exaggeration, extension, expansion, reduction, distorsion, enigmatic imagery, metaphor, metamorphosis, opposition, hyperbaton, polysyllabic epithets, wit, paradox, claroscuro, echo, parallelism, long series of nouns, and the rhythm of the correlaciones recolectivas (Hatzfeld 159-82, 237-50). Given that the playwrights called themselves "poetas," one might be forgiven for thinking that they considered the poetry of their comedias at least as important as their ability to move the plot from one point to the next. In most modern stagings, plot and character (i.e., narrative) are preserved while structure and image (poetry) are sacrificed to the supposed demands of audiences more accustomed to television and film.

By way of example, let us focus on the previously mentioned 1981 production of Calderón's 
fully-sung comedia, Celos aun del aire matan and the aesthetic consequences of performance cuts. For this modern premiere, Robert Baca of the University of Utah served as director, and I was the producer. By way of context, it is important to note that every effort was made to present Celos as it might have been presented in the Coliseo del Buen Retiro; we used Renaissance and baroque instruments for the music, made costumes based on contemporary paintings, and even built our own stage and proscenium arch in a room called the Great Hall in order to approximate the more intimate settings. Of course, some things were either simply beyond our control (the competence of the student performers) or we chose a modern adaptation rather than fetishize the state of technology in 1660 (in other words, we used electricity). Beyond any cuts that we could ascribe to situations beyond our control, we made additional cuts based strictly on aesthetic grounds, just to shorten the running time, a decision that I now believe to have been a mistake. Let us consider one scene in particular.

The scene in question opens Act III (14331508). Diana, furious at Eróstrato for having burned down her temple, sends the Furies out into the world to wreak her revenge. The original scene consists of nineteen verses of three heptasyllabic and one hendecasyllabic line, with an assonant rhyme (u-a) in the even-numbered lines of poetry. Although the rhyme might seem more appropriate to a lengthy narrative in romance, the regular pattern of lines of 7 and 11 syllables definitely gives the text a 
strophic rhythm. In the case of this particular scene, the actress playing Diana (Karen Nickell) was one of the strongest we had, so the decision to cut verses was made almost exclusively to cut out "unnecessary" text and shorten the performance to three 30minute acts. As a result, the first six verses were eliminated, as were verses 15-18 (most of the text sung by the Furies). From a perspective of strictly dealing with plot, not much was lost. The opening lines of Diana merely repeat that Diana is angry at Eróstrato and at Aura (also called Aurora), material familiar to the audience who has seen Act II. The missing lines of the Furies do foreshadow the action to come, that is, what will happen to Céfalo and Pocris, as well as Eróstrato, but the audience will miss nothing as these actions will be performed on stage in the next few scenes. This is the scene as performed at Trinity in 1981, with modernized spelling; the blocked-off text in italics is the text that was omitted.






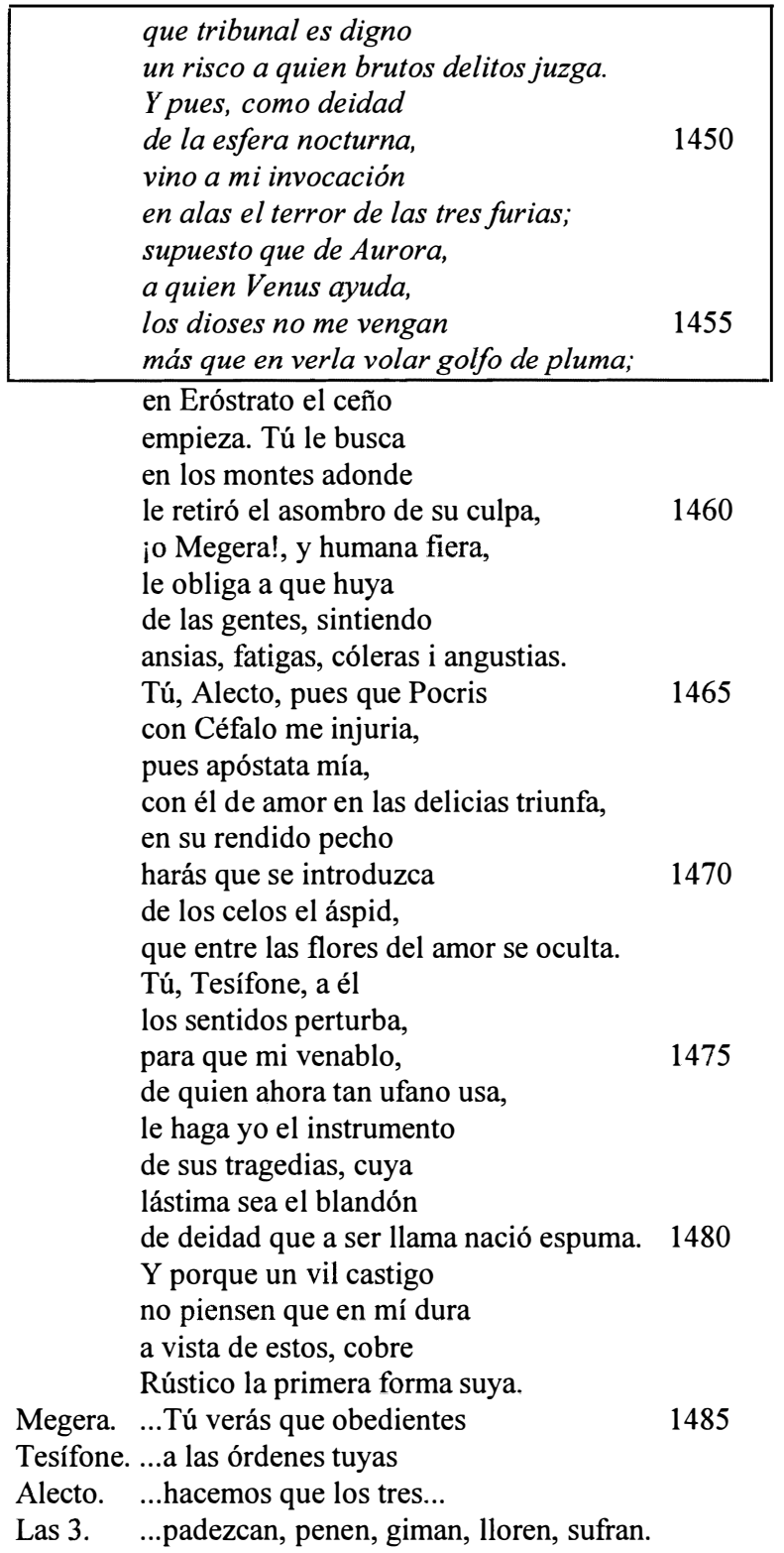




\begin{tabular}{|c|c|c|}
\hline Diana. & $\begin{array}{l}\text { Pues antes que del día, } \\
\text { que a mi pesar madruga, } \\
\text { del monte y del alcázar } \\
\text { corone el capitel, dore la punta. } \\
\text { cada una por su parte } \\
\text { a su ejercicio acuda. }\end{array}$ & 1490 \\
\hline Megera. & $\begin{array}{l}\text { Pues a los riscos, donde } \\
\text { a las gentes Eróstrato se hurta. }\end{array}$ & 1495 \\
\hline Tesifone. & $\begin{array}{l}\text { A los bosques en que } \\
\text { a Aura Céfalo adula. }\end{array}$ & \\
\hline Alecto. & A los palacios, donde & \\
\hline & Pocris de amor la vanidad ilustra. & 1500 \\
\hline Diana. & $\begin{array}{l}\text { A la sagrada esfera, } \\
\text { desde donde yo influya }\end{array}$ & \\
\hline Las 3. & $\begin{array}{l}\text { rigores, que los tres... } \\
\text {...padezcan, penen, giman, lloren, sufran. }\end{array}$ & \\
\hline Alecto. & $\begin{array}{l}\text { Y pues soy la primera } \\
\text { que de Pocris va en busca, } \\
\text { desde esta parte haga } \\
\text { que el palacio en que vive se descubra. }\end{array}$ & 1505 \\
\hline
\end{tabular}

If the reception of performed spoken text is considerably different from the experience of reading the text, the difference between hearing reading text and hearing it sung by a competent voice is nothing less than striking. The music adds a complex and dense dimension of meaning and feeling to the text that is simply not appreciable if the words are only read or spoken. Moreover, one readily picks up on the strophic nature of the passage. The mere rhythmic poetic shift from heptasyllabic to hendecasyllabic lines becomes a concluding musical refrain to the previous three lines. Perhaps most importantly, one hears most clearly the baroque predilection for repetition. This opera was written before lyric theater allowed for set arias, so the artistry of both poet and singer was appreciated not in a brief burst of 
virtuosity but in the repetition of a well-turned musical phrase. (One only need look at the vast repetitions in the architecture of El Escorial to see the same ideal worked out in a different medium.) By cutting half the verses of the song, we definitely undermined the baroque aesthetics that Calderón and Hidalgo worked so hard to incorporate into the play. The suppression of repeated musical verses is joined by the suppression of the most poetic lines. The plot is important dramatically, but Calderón, the poeta, was at least as well known for his brilliant poetic passages that served aesthetic purposes rather than, or at least in addition to, dramatic ones. The breathtaking gongorist imagery of the "esmeralda bruta," "el venenoso monte de la luna," and "verla volar golfo de pluma;" the structural repetition of $n i$ ("ni pompa más suma / ni dosel más excelso"); the hyperbaton of "en pardas ruinas convirtió caducas;" and just the sheer force of the quantity and quality of the words were dropped only to accommodate a modern, impatient audience. It is no coincidence that the list of suppressed features reads like a textbook introduction to poetic style of the period. In short, what we were leaving out were all those elements that responded to baroque aesthetics. In short, we intentionally cut the "baroqueness" out of the passage.

Ours was a university production, but the errors and omissions are not limited to non-professional theater. Let us turn to another example, one by a well-respected and successful modern, professional company, one that was extremely well received by 
the audience at the Chamizal Theater in El Paso. Any cuts made here cannot be attributed only to amateurish decisions made in ignorance by people trying to placate a Texas audience. In selecting the example to go here, one could have picked at random just about any video in the collection of the Association for Hispanic Classical Theater; the cuts that are the target here are virtually universal. The scene in question is from Act II (1335-1486) of Francisco Portes's superb 1991 production of Moreto's El lindo don Diego. The entire passage is one speech by Inés: 150 lines of romance, with an assonant rhyme in e-a. Here she is trying to get Don Diego to turn his attentions elsewhere, one of the many comic scenes with potentially serious overtones found in the play. Of the original 150 lines, Portes has cut out 112, or just under three-fourths of the original speech. (It should be noted that this was not the most egregious cut made in this production. In Act III [2683-2793], Portes cut out 87 of 90 lines, inventing three more to replace those cut. So little remained of Moreto's text that it wasn't even worth reproducing the scene.) Here is the scene as performed, with the omitted text blocked off and in italics:

Señor don Diego, si el lustre 1335

de la sangre que os alienta a su misma obligación se sabe pagar la deuda, ninguna puede ser más que la que agora os empeña,

pues una mujer se vale de vuestro amparo en su pena. 


\begin{tabular}{|c|c|}
\hline $\begin{array}{l}\text { La dificultad está, } \\
\text { para que más os suspenda, } \\
\text { en que, siendo contra vos, } \\
\text { os pido a vos la defensa. } \\
\text { Mas cuanto puedo deberos } \\
\text { os pago en querer atenta } \\
\text { que, si habéis de ser vencido, } \\
\text { vuestro el vencimiento sea. }\end{array}$ & 1345 \\
\hline $\begin{array}{l}\text { Mi padre, señor don Diego, } \\
\text { a cuya voz tan sujeta } \\
\text { vivo, que por voluntad } \\
\text { tiene el alma mi obediencia, } \\
\text { trató la unión de los dos } \\
\text { tan sin darme parte della } \\
\text { que de vos y del intento } \\
\text { al veros tuve dos nuevas. }\end{array}$ & 1355 \\
\hline $\begin{array}{l}\text { Casarme sin mí es injusto: } \\
\text { mas dejo aparte esta queja, } \\
\text { porque al blasón de obediente } \\
\text { tiene algún viso de opuesta. }\end{array}$ & 1360 \\
\hline $\begin{array}{l}\text { La aversión o simpatía } \\
\text { con que apartan o acercan } \\
\text { las almas pende en el cielo } \\
\text { de influjo de sus estrellas. }\end{array}$ & 1365 \\
\hline $\begin{array}{l}\text { Esta es más o menos grave, } \\
\text { según es más la violencia } \\
\text { de los astros que la influyen } \\
\text { la sangre en que se engendra; } \\
\text { de donde la inclinación } \\
\text { no puede ser acción nuestra, } \\
\text { pues sin albedrio un alma } \\
\text { o se inclina o se desdeña. }\end{array}$ & 1370 \\
\hline $\begin{array}{l}\text { Siendo ansí, cuando yo os diga } \\
\text { que mi inclinaci6n no es vuestra, } \\
\text { no os ofendo en la razón, } \\
\text { aunque en el gusto os ofenda. }\end{array}$ & 1375 \\
\hline $\begin{array}{l}\text { Esto supuesto, señor, } \\
\text { no sólo eso el alma os niega, } \\
\text { mas a pecho y mis ojos } \\
\text { hace horror vuestra presencia. } \\
\text { Desde el instante que os vi } \\
\text { discurrió un hielo en mis venas }\end{array}$ & 1380 \\
\hline
\end{tabular}


a que no halla el alma amparo,

1385

más que el que de vos intenta.

$Y$ advertid que ya os declaro

mi aversión con tal llaneza,

porque antes he prevenido

que la inclinación no es nuestra;

y estoy a vuestro decoro

y a vuestro amor tan atenta,

que os di primero el escudo

por no ofender con la flecha.

Casarme con vos, don Diego,

si queréis, ha de ser fuerza;

pero sabed que mi mano,

si os la doy, ha de ser muerta.

De caballero y de amante

faltáis, don Diego, a la deuda

si, sabiendo mi despecho,

vuestra mano me atropella.

De caballero, porque,

por gusto o por conveniencia,

no hacéis precio de la vida

de una mujer sin defensa;

de amante, porque en tal caso

corre el cariño perezas,

y aqui, sin mi voluntad,

queda agraviada la vuestra.

Vencer mi aborrecimiento

mi desdén, si lo fuera

con porfias y festejos,

fuera garbosa fineza;

pero valeros de un medio

donde no está la violencia

de parte de vuestro amor,

sino de quien me sujeta,

$y$ arrastrarme sin vencerme,

es acción tan descompuesta.,

que aja la galantería,

el amor y la nobleza.

Luego en dejarme, aunque ahora

mi sentimiento os lo ruega

más garbo en vos que en mi alivio

vuestro decoro interesa. 


\section{Comedia Performance Vol. 1, No. 1, 2004}

\begin{tabular}{|l|}
\hline Pero aunque destas razones \\
pudiera bastar cualquiera, \\
no quiero yo que esta acción \\
hagáis por ninguna déstas, \\
sino porque yo os lo pido \\
que pues la acción es la mesma, \\
no os quiero yo malograr \\
el mejor fin que hay en ella. \\
Vos don Diego habéis de hacer \\
a mi padre resistencia, \\
y escoged vos en la causa \\
la razón que más convenga. \\
Aborrecedme, injuriadme, \\
que yo os doy toda licencia \\
para tratar mi hermosura \\
desde desgraciada a necia. \\
Despreciadme vos a mí \\
que yo os doy palabra cierta \\
de tenéroslo por bien, \\
aunque sepa que es de veras. \\
Esto os pido, y el secreto \\
que requiere acción como ésta; \\
pues por último remedio \\
a vos mi dolor apela. \\
por la ley de mi obediencia, \\
Haced cuenta que una dama \\
a vencer otro os empeña, \\
que es lance que no le puede \\
excusar vuestra nobleza. \\
Teneos vos para venceros \\
por otro en la competencia, \\
y lograd, de vos mandado \\
a vos vencido, la empresa. \\
Que si por el gran contrario \\
más la vitoria se precia, \\
vos no podéis escoger \\
enemigo de más prendas. \\
Sabed, don Diego, una acción \\
ques por entrambos bien hecha: \\
\hline \\
\hline
\end{tabular}




\begin{tabular}{|ll|}
\hline para cualquiera precepto & \\
el «sì ha de ser mi respuesta. & 1470 \\
Si vos no lo repugnáis & \\
yo no he de hacer resistencia, & \\
y si deseáis mi mano, \\
desde luego será vuestra; \\
pero mirad que os casáis \\
con quien, cuando la violentan \\
sólo se casa con vos \\
por no tener resistencia. \\
Y ahora vuestra hidalguí, \\
el capricho, o la fineza, \\
corte por donde quisiere, \\
que, cuando pare en violencia, \\
muriendo yo acaba todo, \\
pero no vuestra indecencia, \\
pues donde acaba mi vida \\
vuestro desdoro comienza.
\end{tabular}

Again, more than anything else, what has been omitted includes conceptista poetry ("siendo contra vos, / os pido a vos la defensa," "casarme sin mí"), philosophical ruminations ("sin albedrío un alma o se inclina o se desdeña"), statements and explanations (Diego's failings as both "caballero" and "amante," and Inés's subsequent razonamientos to support her decision), and, as a result, the sheer time spent listening to poetry, the flow of words, and the aesthetic effect of a long speech on an audience (not to mention the show of virtuosity on the part of the actress). The Baroque has again been sacrificed to the modern; poetry has given way to drama; aesthetics loses to practicality.

The point is not that modern directors (and audiences) have no right to tinker with old texts. Rather, the trouble is that it is the artistry that mod- 
ern director's want to cut first. Practically nowhere can one see all the actions and all the words in all their baroque splendor in the original language, boring as they may be to mainstream twentieth-century sensibilities. The text may live to be performed another day, but all modern productions seem to approach the text from the same discursive perspective. Despite Miller's correct assertion that all art changes, the radical changes in performance as dictated by fashion do not occur with such universality in other media. In music, a Mozart piece might be adapted as the theme song for Elvira Madigan, but one can still listen to the original. There are smaller orchestras around that play older works to sound much as they did in the eighteenth century, although one can also appreciate the richer sound of the nineteenth-century orchestra applied to the same work. Sidney Berger, who admitted cutting plays, is still concerned that cuts be made most cautiously: "What is at risk, however, particularly in cutting, is the play itself" (Luere 46).

Why is drama so susceptible to these changes that preclude forever the possibility of appreciating a presentation of a full, original text? Let's face facts. An audience is an important part of the theatrical experience. As too many directors and producers know, if you put on a play that no one attends or that the audience dislikes, the result is not a happy event for anyone involved. But there is a real fear that some directors woefully underestimate their audiences. There is a tension between "high culture," the text to which we historically, academi- 
cally, adhere, and popular culture, which sells tickets and is considered, in fact, to be more universally enjoyable. It is clear that directors believe that academics are snobs out of touch with popular culture. Lee Mitchell sneers at the thought of an authentic production that "would of course yield nothing but an historical curiosity" (xii). The comedia is not Shakespeare, however, much less Neil Simon. At least part of the audience for a modern performance of the comedia comes precisely out of "historical curiosity"; otherwise, why not just catch the latest film at the cineplex? Moreover, as was cited earlier, Mitchell is willing to cut text solely for the comfort of the spectator. But is that attitude not likewise snobbish? Mitchell believes that he knows better than the audience what will please them and what works. What ever happened to the notion that art was meant to challenge, to expand one's intellectual horizons? When the comfort of the audience takes precedence over the content of the work, then all we will have is a homogenized, bourgeois medium. Usually we call this network television.

Television is full of plots like those found in the comedia. I have frequently referred to the comedia as the television of its day as far as plot and character are concerned. So why go see an old play when one can see the plot at home for free? Because one is looking for a different aesthetic vision from a different culture and a different era. Not every audience wants to see plays cut to highlight only the plot. At least occasionally, some people would like to hear all the text, all the 
rhythms, all the narratives, and all the images that together form a comedia text. In this regard the comedia today resembles opera more than theater. For the full experience one ought to be able to see a baroque aesthetic on stage in full glory. If music lovers are still able to hear old pieces performed by contemporary instruments in settings similar to those of the original performances, we theatergoers should have the possibility of attending, at least once or twice, productions whose success depends not just on plot and character but also on capturing the essence of the aesthetic experience of the original.

\section{Works Cited}

Berger, Sandy. "Sandy Berger." Playwright Versus Director: Authorial Intentions and Performance Interpretations. Ed Jeane Luere. Advisory ed. Sidney Berger. Westport, CT: Greenwood Press, 1994. 37-48.

Calderón de la Barca, Pedro. Celos aun del aire matan. Ed.

Matthew D. Stroud. San Antonio: Trinity UP, 1981.

Hatzfeld, Helmut. Estudios sobre el barroco, 3a ed. Madrid: Gredos, 1973.

Mitchell, Lee. Staging Premodern Drama: A Guide to Production Problems. Westport, CT: Greenwood Press, 1983. Miller, Jonathan. The Afterlife of Plays. San Diego: San Diego State UP, 1992.

Moreto, Agustín. El lindo don Diego. Ed. Frank P. Casa and Berislav Primorac. 5a ed. Madrid: Cátedra, 1987. 